\title{
Individualised or participatory? Exploring late-modern identity and sustainable development
}

\author{
Lucie Middlemiss* \\ Sustainability Research Institute, School of Earth and Environment, University of \\ Leeds, UK
}

The idea of individualisation is powerful: in late-modern society, people's sense of identity is based on their individual experience rather than their relationships with others. This is problematic for sustainable development because it conflicts with the ideal of participation enshrined in its theory and practice. It is also unclear how the idea plays out in this field, with emerging evidence that some sustainable development policy and practice is individualising. The realities of individualisation are more complex. Empirical studies outside sustainable development have shown that individualising policy does not necessarily have individualising effects. Considering how the idea and realities of individualisation cast new light on subjectivities imagined in sustainable development theory and practice, I argue that sustainable development scholars and practitioners need to consider a range of late-modern subjectivities, and be critically aware of how individualisation is potentially reproduced in policy and practice.

Keywords: individualisation; sustainable development; sustainable consumption; late-modern identity; participation

\section{Introduction}

There is a considerable body of work in social theory, to date largely overlooked by sustainable development scholars, that deals with individualisation (Elias 1991, Beck and Beck-Gernsheim 2002, Campbell 2004, Bauman 2007). In social theory, individualisation is thought to stem from changes in society associated with industrialisation, and the resulting consumer society (ibid.). Authors claim that in a consumer (or late-modern) society, people's sense of identity relates more to their own lives than to how they situate themselves in relation to other people. There are two key implications of this body of work: first, that people are likely to be individualised (in other words, acting and defining themselves primarily as individuals); second, that policy and practice is likely to be

\footnotetext{
*Email: 1.k.middlemiss@leeds.ac.uk
} 
individualising (encouraging people to act and define themselves primarily as individuals).

The idea of individualisation is problematic for sustainable development for two reasons. First, both theory and practice on sustainable development has historically emphasised civic participation as an important means to achieving its ends (Hardin 1968, WCED 1987, Ostrom 1990). There is a long tradition in this work of promoting the participation of citizens in decision making for sustainable development, based on the principle that people are more likely to commit to outcomes to which they have had a collective input (Hardin 1968, Ostrom 1990). A more recent body of work recognises the need for the participation of ordinary people in mitigating the effects of environmental damage through sustainable consumption (Cohen and Murphy 2001). Here, the starting point is that harm inflicted on the environment must be reduced by the modification of lifestyles. The idea of individualisation therefore complicates that of sustainable development because, while civic participation is seen as essential to the creation of a sustainable society, people in late-modern societies may be more individualised and therefore less inclined to participate.

Second, the idea of individualisation has entered the 'common vocabulary of motives' of late-modern society (Dawson 2012). As such, it is highly likely to be played out in sustainable development policy and practice. While individualisation has received limited attention in writing on sustainable development, a number of authors point out the individualising nature of various strands of sustainable development policy and practice (see Maniates 2001, Scerri 2009, Humphery 2010, Middlemiss 2010, Hauxwell-Baldwin 2013). Ironically then, sustainable development policy and practice may in some cases be further individualising the very subjects it is attempting to engage in collective endeavour.

The realities of individualisation add further complexity to this analysis. Empirical and critical work outside of sustainable development tends to contradict the theorists' rather simplistic idea of an individualised society (Charles et al. 2008, Jamieson 1998, Atkinson 2010, Dawson 2012). Empirical evidence suggests that individualisation affects different types of people differently, and that social categories of class, gender, and wealth continue to have an impact on people's experiences. The implication of this messy reality of individualisation for sustainable development is also hugely important to understand. It raises questions such as who participates in the sustainable development project, and who is individualised and how that impacts on their propensity to participate.

This article represents a first attempt to bring together literature from social theory, sociology, and sustainable development to consider how both the idea and the reality of individualisation are likely to impact on attempts to achieve the ideal of sustainable development. This is important because in both the idea and the reality of individualisation, we see threats to the potential to achieve the ideal of participation for sustainable development; unpacking how such a threat might be countered through better policy and practice is critical. The key argument I 
make here is that there is a pressing need to explore late-modern subjectivities in order to understand better how (and, indeed, if) the ideals of participation for sustainable development can be achieved. Sustainable development ideals, and related policy and practice, are clearly influenced by the idea and realities of individualisation. As such, we have a responsibility to understand how these both produce (and potentially reinforce) late-modern subjectivities.

I begin by outlining the idea of individualisation, as defined in social theory, and go on to discuss how this idea is problematic for sustainable development (both because it conflicts with the ideal of participation, and because it is played out in sustainable development policy and practice). I then outline the evidence on the realities of individualisation, as documented in a series of sociological studies. Finally, I discuss the implications of these studies for sustainable development, and propose some future research directions.

\section{The idea of individualisation}

Individualisation has been a key discussion point in social theory in recent decades. This narrative of development sees social changes such as industrialisation, urbanisation, and the rise of consumerism as tied into a gradual shift in our identity. There are two key elements here. First, social forms and groupings are not as relevant to people as they were:

...individualization means the disintegration of previously existing social forms for example the increasing fragility of such categories as class and social status, gender roles, family, neighbourhood etc. (Beck and Beck-Gernsheim 2002, p. 2)

This does not mean that such social forms no longer exist, rather that they can no longer be used to explain people's lives (in terms of class, status, and gender), and that they have less relevance to people's lives (in the case of family and neighbourhood). Beck (1992) characterises these social forms as 'zombie categories': ideas that live on in sociology, despite the transformation of the reality to which they refer. Second, the understanding of the individual and his or her relationship to society has changed. Elias (2000) calls this new self-image homo clausus, which he characterises as 'a little world in himself who ultimately exists quite independently of the great world outside' (p. 472).

For Elias (1991), homo clausus is the current balance between what he calls the I-identity and the we-identity. In modern society, the former is valued over the latter. Gauchet (2000) further claims that in late-modern society, people identify even more strongly as individuals, such that 'demand for authenticity becomes incompatible with the attachment to a collectivity' (p. 32). The centrality of the self plays out in a rich and deep way in people's daily lives. So, for instance, Beck and Beck-Gersheim (2002) argue that in late-modern society, people must 'live a life of one's own': 
...individuals are not so much compelled as peremptorily invited to constitute themselves as individuals: to plan, understand, design themselves and act as individuals - or, should they 'fail', to lie as individuals on the bed they have made for themselves. (pp. 3-4)

The labour market is central here, as education (based on individual achievements), mobility (requiring people to move with their work), and competition among peers all drive towards more individualised societies (ibid.).

Work on individualisation ties into a broader discussion around the changing nature of identity in a late-modern world. Theorists see the advent of a consumer society (being able to create new 'selves' by buying things) resulting in a profound change in our lived experience. As Bauman (2002) explains:

'individualization' consists in transforming human 'identity' from a 'given' into a 'task' - and charging the actors with the responsibility for performing that task and for the consequences (also the side-effects) of their performance. (p. xv)

As membership of class and status groupings are less significant in our lives, our sense of self is more transient, and we adopt and discard identities depending on where we are, who we are with, and what we are doing (Campbell 2004). Further, since our 'self' is more transient, we engage in a 'project of the self', in which we repeatedly reconstitute ourselves in our daily life (Giddens 1991). Many authors comment that this need to work on the 'task' of identity amounts to a reccurring identity crisis, as the side effects of a constantly transforming identity are uncertainty and stress (see, e.g., Beck 1992, Bauman 2000).

Individualisation also has important social outcomes. A central outcome is a change in relationships between individuals. Relationships, such as family ties and marriage, are no longer permanent and non-negotiable. This results in new freedoms, on the one hand (people being able to walk away from abusive relationships), but it also means that people have to reflect on the nature and status of their relationships (Elias 1991). Relationships are therefore more deliberate and reflexive: 'they have to be established, maintained and constantly renewed by individuals' (Beck and Beck-Gernsheim 2002, p. 35). Community ties are also transformed by individualisation; these are weakened as a result of people's increased mobility and competitiveness. Giddens talks of a process of disembedding of social relations from place, leaving geographic community less relevant for explaining the world (Giddens 1990). Further, collective action is weakened because of this breakdown in the 'zombie categories', such that an individual's problems no longer sum up to a common cause:

The sole advantage the company of other sufferers may bring is to reassure each one that fighting troubles alone is what all the others do daily - and so reinvigorate the flagging resolve to go on doing just that. (Bauman 2002, p. xvii) 
Despite this tendency to identify less clearly with the collective, theorists note a growth in interest in the rights of the individual, and concern for human rights more generally. This is evidence of a 'new global sense of responsibility for individuals in distress, regardless of their state or their tribe' (Elias 1991, p. 168).

In summary, then, social theorists writing in this area describe a new kind of subjectivity. In the late-modern world, people are less connected with others (whether in families, communities, or romantic relationships) and more concerned with themselves. Indeed, the reflexive project of identity that theorists describe is time-consuming and leaves little impetus for collective action. It is important at this point to note that while there is strong agreement as to the nature of late-modern identity, this literature mainly consists of theory as opposed to empirical observation. As such, I characterise this work as being concerned with the idea of individualisation. From here, we move to our arguably contradictory concern in considering the ideal of participation in sustainable development.

\section{Conflict of individualisation with the ideal of participation in sustainable development}

Writers and practitioners have long maintained that participation is a central means of achieving the social goal that is sustainability. Key economic thinkers on the environment, who realised that the actions of rationally acting individuals could not be depended upon to ensure the survival of the planet, proposed participation in decision-making, or collective action, as a solution. More recently, writers on sustainable consumption have argued that the participation of individuals and communities is essential to efforts to mitigate environmental damage. Both of these amount to a form of civic participation, under an interpretation of citizenship that includes action in both the public and private spheres (Scerri and Magee 2012, Hobson 2013). Here, I give a short summary of the importance of participation in work on sustainable development, and the subcategory of sustainable consumption. I also highlight critical perspectives on participation for sustainable development which, together with the idea of individualisation, problematise the reliance on participation as an ideal in sustainable development thinking.

In 'The tragedy of the commons', the ecologist Garrett Hardin (1968) tackles the issue of population growth, freedom from restraint, and the connection to ecological collapse. In doing so, he challenges a key tenet of economics: the belief that a rational actor acts both in their own interests and in the interests of society at large. Hardin's story of the herdsman offered access to graze his animals on common land, and the inevitable ecological collapse that ensues as the commons is overgrazed, is a central problematic in sustainable development. It also represented a powerful challenge to economists; as Elinor Ostrom (1990) pointed out, the idea that rational individual action leads to irrational social 
outcomes 'seems to challenge a fundamental faith that rational human beings can achieve rational results' (p. 5).

Where Hardin sees 'mutual coercion' as the solution to this commons problem, Ostrom outlines a series of conditions under which common pool resources can be successfully managed (ibid.). Central to these conditions is the idea of participation: in particular that people will behave in the common interest if they are able to participate in the institutions that are established to manage the resource in question. Participation, in decision making in particular, is called upon in all of the key documents on sustainable development as a mechanism for change. For instance, the Brundtland report claims that 'effective participation in decision-making processes by local communities can help them articulate and effectively enforce their common interest' (WCED 1987, p. 47). The centrality of participation in the environmental movement also hinges on its nature as a radical movement, which tends to believe that the way to include people in change is through deliberative democracy. The assumption here is that 'when citizens are actively involved in ... open and multi-level social discussions on the overall reduction of consumption levels and the value of earth-friendly lifestyles, they will recognize the advantages of a different attitude towards wasting resources and treating nature with greater care'(de Geus 2004, p. 96).

Another relevant body of work here is that on sustainable consumption, which does not consistently use the terms 'participation' or 'collective action', but does take the starting point that people need to make changes in their daily lives for the sake of the common good. As we will see later, some of the theory, policy, and practice in this area has been individualising, with a tendency to attribute responsibility for change to the individual. Further, there is a tendency to characterise all consumption-related activity as 'individualistic, irresponsible and apolitical' (Barnett et al. 2010, Miller 2012). Barnett et al. offer a more optimistic voice in this debate, identifying consumer activism as a new domain of participation (ibid.). Indeed, they see the emergence of activism on ethical consumption as an organised and collaborative effort, in which collective actors attempt to stimulate change for social good. In recent years, theory and practice linking sustainable consumption and community has also begun to emerge, recognising that consumer action might need social support (Seyfang 2009, Middlemiss 2011a, 2011b). In practice, a host of initiatives have emerged at the local level to address global environmental issues, and promote sustainable consumption (e.g. Transition Towns, Incredible Edible, Carbon Rationing Action Groups).

In recent work on participation in sustainable development, more critical voices have emerged. Writers in this journal have objected to assumptions that participation is a way of opening up the political process, and as such that it has positive consequences for sustainable development. Blühdorn (2013) argues that participation in sustainable development is being used as a form of governmentality, refashioning the democratic ideals of the environmental movement into a tool for sustaining 'unsustainability'. Similarly, Scerri talks of a deliberate neutralisation of sustainable development through stakeholder citizenship 
which reframes participation as 'an instrumental benefit: available through the exercise of preferences, made possible through individual achievements in the pursuit of aspirational goals' (Scerri 2009, p. 474). Both Blühdorn and Scerri's work has strong resonances with Beck's work on risk society and individualisation (Beck 1992). The experience that Blühdorn (2013) describes - '...the plethora of seductive opportunities for self-realization, the frantic struggle against mounting uncertainties and the management of increasingly complex personal lifestyles reduce the time and energy available for democratic participation and social responsibility' (p. 26) - mirrors Beck's vision of the late-modern project of identity, which requires people 'to plan, understand, design themselves and act as individuals' (Beck and Beck-Gernsheim 2002, pp. 3-4), meaning that participation in collective endeavours is both less relevant and less achievable (see also Bluhdorn 2006). Unlike Beck, both Blühdorn and Scerri are critical of the outcome of such changes to participation: the neutralisation of politics and the maintenance of the status quo. Scerri and Magee also see 'stakeholder citizenship' as an institutional response to what they call 'individuated' societies: they see individualising policies as a means of reinforcing a belief that societies are individualised (Scerri and Magee 2012).

Both the critical understanding of participation in the sustainable development literature, and the broader literature on individualisation, suggest that the maintenance of the ideal of participation for sustainable development amounts to overly positive thinking on the part of its proponents. In essence, participation enthusiasts are positing an idealised participatory subject fit to build a sustainable future, an individual that is willing to work with others to reach decisions or modify their lifestyle for the greater good. It is unclear whether this idealised participatory subject exists. While work on ethical consumerism and community-based sustainable consumption might suggest such an emergence of participatory enthusiasm (Seyfang 2009, Barnett et al. 2010), the wealth of sociological research that suggests a different kind of subjectivity (preoccupied with the project of identity) is largely ignored in writing on sustainable development. There are potentially serious implications here for sustainable development thinking, as well as for policy and practice. First, if proponents of sustainable development adopt an overly positive view of participation in theory, its practical and policy recommendations may be undermined by late-modern subjectivities. Second, and this I will deal with in depth in the next section, a lack of awareness of individualisation may be resulting in sustainable development policy and practice that reinforces latemodern subjectivities. Indeed, as we will see, in the limited number of studies looking critically at sustainable development policy and practice, the idea of individualisation arises in some strange and counter-intuitive places.

\section{Individualisation and the policy and practice of sustainable development}

The idea of individualisation certainly has a bearing on the policy and practice of sustainable development. While there are limited studies in this area, a series of 
recent critiques have begun to reveal a complex picture about how both the ideal of participation and the idea of individualisation translate into action. This work has rather inevitably emerged from the subcategory of sustainable consumption, given its focus on the lifestyles of individuals, and as such that will be a focus here. These studies take a critical approach, with (sometimes explicit) parallels with work on green governmentality, as helpfully summarised by Hobson (2013). The questions being asked also mirror those that Hobson sets out: 'what particular problems are being illuminated and what is being obscured?; what forms of self are presupposed by these practices of governance and what transformations are sought' (ibid., p. 60). Before I discuss this work in more detail, it is important to note that sustainable development is not the only area of policy and practice that is affected by the idea of individualisation, and some insights from broader work in this area are a useful starting point.

The idea of individualisation has entered what Dawson (2012) calls the 'common vocabulary of motives' in late-modern society. This represents a shift in collective understandings of how and why people act. In empirical studies outside of sustainable development, researchers have found that the idea of individualisation has become prominent in a variety of policy areas, with a knock-on effect on the design of policy. For instance, in UK family research, Charles et al. (2008) note that the idea of individualisation has been internalised by politicians, and has directly impacted on the design of family policy. As they put it:

It is almost as if New Labour has read the individualization thesis as an accurate representation of what is happening to families and individuals and is developing policies on this basis. (p. 216)

This assumption of individualisation in family policy is problematic, as it creates tensions when, on the one hand, policy assumes an individualised family structure, an 'adult-worker model' as opposed to a 'male-breadwinner model', but, on the other hand, attempts to promote social capital. Charles et al. argue that if this 'adult-worker model' does not exist already, it will come into being simply because it is assumed to exist by the makers of family policy.

This leads us to some important questions. Does sustainable development policy assume individualisation? Is it individualising? Any answer to these questions has to be provisional, given researchers' limited engagement with the concept of individualisation to date. The first source here is a paper by Maniates (2001) in which he shows how the 'individualisation of responsibility' has become a central discourse of the US environmental movement. In the face of potentially catastrophic environmental change, the Environmental Defense Fund, a US NGO, calls on its members to recycle, conserve energy, and plant trees. Maniates makes two key points: first, that these strategies are inadequate to solve the challenges posed by global environmental change; and second, that they have become internalised by Americans for whom an appropriate response to 
environmental problems is to shop greener and recycle, rather than to act collectively and/or politically. At the very least, individualising policy of this sort is unsatisfactory because it suggests that the agency of the individual is all that is required to address systemic environmental problems (Middlemiss 2010). Maniates also has political objections to individualising policy and practice. In the consumption context, individualisation positions the subject as a consumer rather than as a citizen. As Maniates (2001) puts it:

Individualization, by implying that any action beyond the private and the consumptive is irrelevant, insulates people from the empowering experiences and political lessons of collective struggle for social change and reinforces corrosive myths about the difficulties of public life. (p. 44)

In effect, Maniates claims that individualising policy on sustainable development produces individualisation by closing down more collective responses to environmental problems.

The Environmental Defense Fund example is useful because it shows how the participatory ideal in sustainable development theory is not necessarily present in sustainable development action. On closer analysis, an assumption of individualisation is also apparent in other areas of sustainable consumption theory and practice. Proponents of voluntary simplicity, for instance, suggest that people can overcome structural barriers, choosing a simpler, happier, less materialistic life. The idea that voluntary simplicity can result in increased well-being is individualising because it understands the motivators of anti-consumerism (and, indeed, well-being) to be purely products of choices by individuals (Humphery 2010). This is problematic, again, because it assumes individual agency will provide the solution to sustainable development, as opposed to more structural changes:

If consumerism is essentially a product of mentality, if it is a cultural logic that works on individual minds, then this eclipses in importance an attention to consumerism as an economic logic and a field of enforced social practice undergirding the control of capital, the organization of production, the design of urban and suburban environments, the nature of transport, the uses of communication technologies, the structure of households and the processes of retail distribution. (Humphery 2010, p. 73)

In a contribution to the new body of work on sustainable consumption and community, Hauxwell-Baldwin (2013) also finds that British government policy on community energy individualises the recipients of funding and its intended beneficiaries. In particular, the Low Carbon Communities Challenge, run by the Department for Energy and Climate Change in the late 2000s, despite being billed as a community initiative, promoted a 'save energy, save money' message, which assumed a self-interested, rational subjectivity among participants in this collective endeavour. This example is particularly intriguing given that it, on the 
one hand, espouses sustainable development objectives of participation ('community' energy), and, on the other hand, assumes people will only act if they see a benefit to themselves as individuals.

It is clear then that a range of actors (here, a US NGO, voluntary simplifiers, and a UK government department) are reproducing the idea of individualisation in their policy and practice. There is also evidence, however, of the subjects of individualising policy and practice being aware that such attempts at reproducing individualisation are happening. Both Hobson (2002), on the basis of qualitative work, and Scerri and Magee (2012), on the basis of a survey, have observed that people are aware of, first, the weakness of a political strategy that relies on individuals taking responsibility for solving environmental problems, and second, the tension between economic growth and environmental solutions. Given this awareness, Scerri and Magee argue that individualising policy risks undermining public support for sustainability, as people seem to understand that it is likely to be rather toothless (ibid.).

We cannot leave this discussion without noting that individualisation follows a logic within neo-liberal governance which has further implications here. Intriguingly, there is disagreement about this link, with theorists Beck and Beck-Gernsheim (2002) rejecting any connection between neo-liberalism and individualisation, while empiricists Charles et al. (2008) argue that the 'reflexive subject of Beck and Giddens is precisely the autonomous individual of liberal thought' (p. 8). In any case, being aware of the broader literature critical of neoliberalism is important, as it suggests a further political critique: that individualisation is a deliberate strategy to offload responsibilities of the state to the individual.

Castree (2008) identifies such a deliberate strategy in neoliberal states' attempts to manage nature:

...the state might make formal efforts to encourage citizens to take personal or communal responsibility for the 'goods' and 'bads' that arise from nature's neoliberalisation. (p. 149)

This extends also to the encouragement of 'communities' to provide services that states used to provide, effectively to take responsibility so that the state can be 'rolled back'.

Intriguingly, the displacement of responsibility to the individual or to community level is a political strategy that is espoused by both neo-liberals and grassroots environmental activists (McCarthy 2005). For neo-liberals, the localising agenda fits in with their belief in a small state; for grassroots activists, it complements an emphasis on bottom-up change (ibid.). Given the influence of neo-liberalism on the politics of many developed world states, and the sustained fascination with small-scale action in the environmental movement, both these political perspectives are likely to have an impact on the policy and practice of sustainable development. 
In summary, there is no systematic analysis to date of how the idea of individualisation plays out in sustainable development policy and practice, and how, indeed, it links with the ideals expressed by broader political movements such as neo-liberalism. Further research in this area is, in my view, essential, since initial evidence above suggests that as a result of this lack of engagement with the idea of individualisation, at least some sustainable development policies and practices are working against the ideal of participation. This situation is further complicated by a series of empirical studies of individualisation from other fields, which suggest that the idea of individualisation is complicated by day-to-day realities. The following section expands upon the realities of individualisation in more detail.

\section{The realities of individualisation}

The idea of individualisation is contested by empiricists working outside of sustainable development. In studies of the family (Charles et al. 2008), class (Atkinson 2010), and intimate relations (Jamieson 1998), a series of authors point out that individualisation is not as widespread in people's daily lives, or as universal an experience, as the theorists imply. The most basic critique, then, is that individualisation as a theory is contradicted by the realities uncovered by empirical research (Dawson 2012). Having said this, the empiricists recognise that individualisation is also a powerful idea, which influences the way people think and act, policy and practice. As such, it is important to understand how existing evidence complicates the idea as it stands. To that end, I will outline a series of critiques of individualisation stemming from this diverse body of empirical work. Note that none of these critiques stems from work on sustainable development, as to date no one has investigated individualisation empirically in this area. There are, however, some interesting parallels between my approach here and that of Hobson in her work on green governmentality (2013). This section is in a sense an attempt at 'realist governmentality': an outline of the 'empirical reality as experienced' in contrast to the 'top-down universalistic' idea of individualisation (ibid., p. 61).

The first set of critiques revolves around the way the 'story' of individualisation is told. This raises several problems. First, there is only one narrative of change (people are becoming more individualised) which results in a binary understanding of people's position in relation to the concept -you are either reflexive (individualised) or traditional (Charles et al. 2008). In promoting this one narrative, other subjectivities are ignored, which can be particularly problematic in relation to marginalised groups (as discussed below) and is not reflective of empirical realities. Second, it paints a nostalgic picture of the past, and an apocalyptic vision of the future. Critics would argue that neither of these positions is justified, further that they reinforce the monolithic narrative of change outlined above. As Jamieson (1998) points out, the story of the 'death of community' is 'part of a conservative rhetoric which contrasted a rosy past in 
which everybody helped and was friendly to everybody with an unpleasant selfish present' (p. 80).

In their extensive restudy of families in Swansea, Charles et al. (2008) find that many of the assumptions we hold about the past (greater social capital, stronger family networks) are not supported by empirical work. Further, they find that individualisation may have positive consequences for society. Instead of breaking down family and community bonds entirely, individualisation seems to have changed the rules around engagement with others. As they explain:

Individuals understand the importance of contributing to society and the inevitability and necessity of social connectedness but direct their own behaviour according to internalised standards rather than following externally imposed rules. (ibid.)

They call this condition 'moral individualism' as opposed to the more bleak 'anomic individualism' posited by theorists. Intriguingly, Dawson (2012) also finds evidence that 'individuals feel an increased responsibility for and emotional attachment to others' as a result of the attribution of responsibility that results from individualisation (p. 310).

The second set of critiques refer to the so-called 'zombie categories' (Beck 1992 ) - the traditional sociological concepts (such as class, gender, family, etc.) which theorists claim no longer offer useful explanations for late-modern life. Critics object in two ways to this dismissal of social categories: first, they point out that the 'zombie categories' still determine inequalities in late-modern life, and second, that identification with those categories still occurs (Dawson 2012). From a feminist perspective, the dismissal of gender as a category is highly problematic because it emphasises symbolic forms of identity (those constructed by the reflexive subject) above embodied ones (gender). It also fails to ring true with lived experiences, as Charles et al. (2008) point out.

...for women, individualization is a contradictory process which conflicts with embodied aspects of female identity such as 'being there' for others and their responsibility for care work and emotion work within families and intimate relationships. (p. 7)

This does not mean that women are not affected by individualisation; indeed, it is likely to mean that women have to work harder at identity formation in order to maintain multiple identities (Dawson 2012). Assuming that families are individualised is equally problematic because it would imply that care relations (typically gendered) are breaking down, when the evidence shows that this is not the case (Charles et al. 2008).

It is rather crude to characterise the theoretical work in this area as monolithic; both Bauman and Beck, for instance, recognise that class influences how people experience individualisation (Atkinson 2007, 2008). Empirical analyses also comment on the importance of class, with 
individualisation more likely to be experienced by the middle classes (Dawson 2012). Recent work on the lived experience of poverty further complicates this analysis, however. In their extensive study of poverty in the UK, Shildrick et al. (2013) find that poverty is conceptualised among the poor as resulting from personal failure (individualised) and that 'poor' people make great efforts to distance themselves from the 'undeserving poor', in other words eschewing any kind of solidarity with people undergoing similar experiences. It seems that the evidence to date paints a range of experiences of individualisation, which can be shaped by sociological categories but which are by no means simply determined by one's position.

It is becoming clear then that individualisation affects different people differently, and that sociological (or 'zombie') categories still have relevance in explaining this. In summarising his critical review of individualisation, Dawson (2012) finds that an important thrust of critique in empirical work is that the idea of individualisation makes more sense if you look at it socially. He posits an 'embedded' understanding of individualisation in contrast to the 'disembedded' formulation more commonly used by theorists. Dawson claims that 'disembedded individualisation', which notes 'the disappearing significance of social characteristics previously taken as impacting social action', has largely been rejected in the body of critical and empirical work done in this area (ibid.).

This more nuanced understanding of individualisation, emerging from empirical and critical work, which refutes the monolithic and apocalyptic narratives common in theoretical work and reclaims sociological categories as powerful tools of explanation, suggests more hopeful consequences for sustainable development. It also suggests potentially different routes to change through policy and practice. If people are morally individualistic, it would make sense to try and engage their 'internalised standards' in the interests of sustainable development, and to build a sense of virtue around individual acts. This would necessitate some understanding of what people's internalised standards are, and how these might be malleable in the interests of sustainable development. Given that people seem to be individualised to a greater or lesser degree, or in different ways and to different ends, this also suggests that encouraging people to engage with sustainable development may be more or less challenging according to people's circumstances. Certainly, the diversity of experience of individualisation suggests that a diversity of strategies for participation in sustainable development are necessary.

\section{Understanding the implications for sustainable development}

The bodies of work on the idea and realities of individualisation pose some important challenges for understanding sustainable development. Work on the idea of individualisation points to a need for sustainable development theory and policy to understand the imagined subjectivities implicit in its claims and recommendations. Work on the realities of individualisation suggests a need 
for sustainable development theory and policy to foster a nuanced understanding of the lived experience of its subjects. There is also room for a critical examination of sustainable development policy and practice in the light of the idea of individualisation: to ask questions about the subjectivities that policy and practice imagines, and how far this means that sustainable development policy and practice individualises its subjects. I will discuss each of these challenges in turn.

As we have seen, the theoretical work on the idea of individualisation paints a rather monolithic picture of the state of identity. In much of this literature, one could be forgiven for thinking that everyone defines themselves as independent from the world and that the 'zombie categories' of family, community, and so on no longer have relevance at all. The empirical evidence on the realities of individualisation is not nearly so clear-cut. Understanding who experiences individualisation and who does not is an important objective for the social sciences in general. Indeed, we need to understand better the range of latemodern subjectivities that manifest themselves in different domains of people's lives. The studies outlined above go some way towards revealing the complexity of the lived experience in a particular domain (e.g. family, work) and its relationship with the concept of individualisation (Charles et al. 2008, Shildrick et al. 2013). There are still some important questions outstanding, however. If someone experiences individualisation in one domain of life, how does that affect the other domains, for instance?

The fact that research on individualisation and late-modern identity is incomplete and contradictory poses a challenge for work on sustainable development. This is not helped by the rather idealised vision of a participatory subject that is apparent in work on sustainable development, which, as I have said, fails to take into account late-modern subjectivities. The starting point for sustainable development research surely has to be to take work on late-modern subjectivity more seriously. In that vein, my survey of the work on both the idea and reality of individualisation throws up some powerful questions for work on sustainable development, around participation and individualisation in particular. Who participates in sustainable development? Does individualisation impact on people's propensity to participate, and in what way? What kinds of subjectivities are imagined by, and written into, sustainable development policy and practice? How do these imagined subjectivities in turn affect reality? These rather general questions pose a challenge for future research.

I also propose some more specific research aims, based on the theoretical and empirical work above. For instance, given that individualisation seems to affect certain people more than others, it is possible that only some people will be able or willing to participate in sustainable development (those that are not individualised). This may not be a problem: for instance, if the majority of people are able to participate in solving a particular sustainable development problem, this may have enough of an effect. On the other hand, there is not an equal distribution of environmental impact. For instance, the wealthy are both thought to be both more individualised and known to be more polluting (Druckman and 
Jackson 2009). There is a justice issue here: it would surely be unfair to require less polluting (and less individualised) people to shoulder the burden of environmental mitigation. More pragmatically, in order to understand how best to design and implement participation for sustainable development, we will need to understand who is and who is not individualised, what their environmental impact is in the first place, and how individualisation affects the likelihood of their participation.

It is clear that in some areas of sustainable development policy and practice, assumptions of individualisation are already being made. As Maniates (2001) and Humphery (2010) point out, in the diverse range of action aimed at engaging ordinary people in more sustainable lives (which might broadly be termed sustainable consumption policy and practice), there is a tendency to assume that people react rationally to incentives, and that they react as individuals. There is to date very little research which examines the range of subjects imagined in sustainable development policy and practice more broadly. The growth in policy and action associated with community or grassroots solutions to sustainable development would suggest that conceptualisations of less individualised environmental subjects are being drawn on (Hopkins 2008, Seyfang 2009). However, Hauxwell-Baldwin's (2013) commentary on government community energy initiatives suggests a half-hearted attempt to engage ideas of the collective masking a broader commitment to individualised policy. The key question here is what such action signifies. It could be interpreted through a neo-liberal lens as a rollback of the state, or, perhaps more charitably, as a recognition of the need to incorporate individualised subjectivities. Further analysis of a broader range of sustainable development policy and practice would be useful here.

In summary, then, current practice and policy on sustainable development is rather complex. Policy and practice exists that is likely to individualise people, by placing the responsibility for environmental and social improvements on their shoulders. On the other hand, there are also initiatives that assume a level of identification and collaboration with others that individualisation is likely to militate against. At the least, people are receiving mixed messages about appropriate reactions to sustainable development problems, sometimes in the space of one specific policy. As such, some important questions remain. What is the experience of the subjects of this policy and action? How do people reconcile these kinds of mixed messages? These questions have begun to be answered by Hobson (2002) and Scerri and Magee (2012), the latter suggesting that there is a risk that individualising policy is creating greater divisions between 'green' and 'brown' citizens (Crook and Pakulski 1995). Next steps in this area must be to understand the impacts of individualising policy and practice on the subjects themselves. 


\section{Conclusions}

As we have seen, social theorists have tended to present a rather simple narrative of individualisation, in which, over time, people become increasingly disconnected from others and focused on their own project of self. This idea of individualisation is complicated by the realities seen in empirical evidence. There is no doubt that society has changed, and that in late-modern times, people have different experiences of social relations and of their own identities from those of earlier generations. On the other hand, these experiences are varied, nuanced, and impacted upon by the complexities of people's life contexts.

Bringing these insights from social theory and sociology to the study of sustainable development problematises a key tenet of theory and practice in this field. As we have seen, sustainable development theory puts collaborative social processes at the heart of its strategy for change, in the guise of 'participation'. Given the changes to social relations and identity that studies of individualisation uncover, the ideal of participation for sustainable development is problematic even in a partially individualised world. Further, early indications show that some sustainable development policy and practice is likely to be reproducing individualisation, an outcome that is surely counter to the movement's aspiration to participation.

I have argued that a deeper appreciation of late-modern subjectivities, and their impact on the ideal of participation is needed, and propose a series of research directions that would help to achieve this. Understanding late-modern identity in the context of sustainable development will allow us to understand if, and in which circumstances, people experience individualisation, and if, and how, sustainable development policy individualises. It will also bring us closer to being able to 'do' sustainable development in a socially sensitive manner.

\section{Acknowledgements}

This research was funded by a fellowship under the Economic and Social Research Council's (ESRC) Sustainable Practices Research Group (SPRG).

\section{Funding}

This work was supported by the Economic and Social Research Council [ES/G035423/1]

\section{References}

Atkinson, W., 2007. Beck, individualization and the death of class: a critique. The British Journal of Sociology, 58 (3), 349-366. doi:10.1111/j.1468-4446.2007.00155.x

Atkinson, W., 2008. Not all that was solid has melted into air (or liquid): a critique of Bauman on individualization and class in liquid modernity. The Sociological Review, 56 (1), 1-17. doi:10.1111/j.1467-954X.2008.00774.x 
Atkinson, W., 2010. Class, individualization and late modernity: in search of the reflexive worker. Basingstoke, UK: Palgrave Macmillan.

Barnett, C., et al., 2010. Globalizing responsibility: the political rationalities of ethical consumption. Chichester, UK: Wiley.

Bauman, Z., 2000. Liquid modernity. Cambridge: Polity Press.

Bauman, Z., 2002. Foreword: individually, together. In: U. Beck. and E. Beck-Gernsheim. eds. Individualization: institutionalized individualism and its social and political consequences. London: Sage Publications Ltd, xiv-xix.

Bauman, Z., 2007. Consuming life. Cambridge, UK: Polity.

Beck, U., 1992. Risk society: towards a new modernity. London: Sage.

Beck, U. and Beck-Gernsheim, E., 2002. Individualization: institutionalized individualism and its social and political consequences. London: Sage Publications Ltd.

Blühdorn, I., 2006. Self-experience in the theme park of radical action? Social movements and political articulation in the late-modern condition. European Journal of Social Theory, 9 (1), 23-42. doi:10.1177/1368431006060461

Blühdorn, I., 2013. The governance of unsustainability: ecology and democracy after the post-democratic turn. Environmental Politics, 22 (1), 16-36. doi:10.1080/ 09644016.2013.755005

Campbell, C., 2004. I shop therefore I know that I am: the metaphysical basis of modern consumerism. In: K.M. Ekström. and H. Brembeck. eds. Elusive consumption. Oxford: Berg, 27-43.

Castree, N., 2008. Neoliberalising nature: the logics of deregulation and reregulation. Environment and planning. A, 40 (1), 131-152. doi:10.1068/a3999

Charles, N., Davies, C.A., and Harris, C., 2008. Families in transition: social change, family formation and kin relationships. Bristol: Policy.

Cohen, M. and Murphy, J., 2001. Exploring sustainable consumption: environmental policy and the social sciences. Oxford: Pergamon.

Crook, S. and Pakulski, J., 1995. Shades of green: public opinion on environmental issues in Australia. Politics, 30 (1), 39-55.

Dawson, M., 2012. Reviewing the critique of individualization: the disembedded and embedded theses. Acta Sociologica, 55 (4), 305-319. doi:10.1177/ 0001699312447634

de Geus, M., 2004. The environment versus individual freedom and convenience. In: M. Wissenburg and Y. Levy, eds. Liberal democracy and environmentalism. London: Routledge, 87-99.

Druckman, A. and Jackson, T., 2009. The carbon footprint of UK households 1990-2004: a socio-economically disaggregated, quasi-multi-regional input-output model. Ecological Economics, 68 (7), 2066-2077. doi:10.1016/j.ecolecon.2009.01.013

Elias, N., 1991. The society of individuals. New York, NY: Continuum International Publishing Group.

Elias, N., 2000. The civilizing process: sociogenetic and psychogenetic investigations. Chichester, UK: Wiley-Blackwell.

Gauchet, M., 2000. A new age of personality: an essay on the psychology of our times. Thesis Eleven, 60, 23-41. doi:10.1177/0725513600060000004

Giddens, A., 1990. The consequences of modernity. Cambridge: Polity Press.

Giddens, A., 1991. Modernity and self-identity: self and society in the late modern age. Stanford, CA: Stanford University Press.

Hardin, G., 1968. The tragedy of the commons. Science, 162 (3859), 1243-1248. doi: $10.1126 /$ science. 162.3859 .1243

Hauxwell-Baldwin, R., 2013. Tackling climate change through community: the politics and practice of the low carbon communities challenge Thesis (PhD). University of East Anglia. 
Hobson, K., 2002. Competing discourses of sustainable consumption: does the 'rationalisation of lifestyles' make sense? Environmental Politics, 11 (2), 95-120. doi: $10.1080 / 714000601$

Hobson, K., 2013. On the making of the environmental citizen. Environmental Politics, 22 (1), 56-72. doi:10.1080/09644016.2013.755388

Hopkins, R., 2008. Transitions handbook. Dartington: Green Books.

Humphery, K., 2010. Excess: Anti-consumerism in the west. Polity Pr.

Jamieson, L., 1998. Intimacy: personal relationships in modern societies. Cambridge: Polity Press.

Maniates, M.F., 2001. Individualization: plant a tree, buy a bike, save the world? Global Environmental Politics, 1 (3), 31-52. doi:10.1162/152638001316881395

McCarthy, J., 2005. Devolution in the woods: community forestry as hybrid neoliberalism. Environment and Planning A, 37, 995-1014. doi:10.1068/a36266

Middlemiss, L.K., 2010. Reframing individual responsibility for sustainable consumption: lessons from environmental justice and ecological citizenship. Environmental Values, 19, 147-167. doi:10.3197/096327110X12699420220518

Middlemiss, L., 2011a. The effects of community-based action for sustainability on participants' lifestyles. Local Environment, 16 (3), 265-280. doi:10.1080/ 13549839.2011.566850

Middlemiss, L., 2011b. The power of community: how community-based organizations Stimulate sustainable lifestyles among participants. Society and Natural Resources, 24, 1157-1173. doi:10.1080/08941920.2010.518582

Miller, D., 2012. Consumption and its consequences. Cambridge: Polity.

Ostrom, E., 1990. Governing the commons: the evolution of institutions for collective action. Cambridge: Cambridge University Press.

Scerri, A., 2009. Paradoxes of increased individuation and public awareness of environmental issues. Environmental Politics, 18 (4), 467-485. doi:10.1080/ 09644010903007344

Scerri, A. and Magee, L., 2012. Green householders, stakeholder citizenship and sustainability. Environmental Politics, 21 (3), 387-411. doi:10.1080/09644016.2012.671571

Seyfang, G., 2009. The new economics of sustainable consumption: seeds of change. Basingstoke: Palgrave Macmillan.

Shildrick, T., et al., 2013. Poverty and insecurity: life in low-pay, no-pay Britain. Bristol, UK: The Policy Press.

The World Commission on Environment and Development, 1987. Our common future. Oxford: Oxford University Press. 